\title{
IMMUNOHISTOCHEMICAL STUDY OF EPITHELIAL CELL MARKERS IN INVERTED PAPIILOMA OF THE NOSE AND PARA - NASAL SINUSES
}

\author{
By \\ Nagwa, M. Helal; Abdel - Hamid, A.; \\ Tawfik A. and Ghonim, M. R.
}

From

The Pathology and E.N,T. Departments, Mansoura

Faculty of Medicine

Received for Puplication : 30/12/1990

\section{INTRODUCTION}

mverted papilloma is an unusual tumour of the nose accounting for less than $1 \%$ of nasal tumours (Snyder and Persin, 1972). Although it is essentially a benign lesion, it has a marked propensity for recurence and can be locally destructive. Occasionally inverted papilloma is associated with malignancy, the exact nature and frequency of these relationship is unknown (Gayle and Woodson, 1985).

Our aim is to use epithelial surface markers to investigate the expression of keratin, epithelial membrane antigen $(E, M, A$,$) and carcino-embryonic$ antigen $(C, E, A$,$) in an attempt to help$ the correct diagnosis of premalignant 159 cases and consequently the management of such cases.

\section{MATERIAL AND METHODS}

This study was done on nine patients, The surgical specimens were obtained from E N T. Department at Mansoura University Hospital. The specimens were fixed in $10 \%$ formaline and then processed as paraffin blocks. Serial 4 um paraffin sections were made and stained with Haematoxylin and Eosin for routine study.

The antibodies were kindely supplied by Dr. K. Geboes. Proffessor of Pathology Leuven University, Belgium. They include polyclonal antikeratin antibody and monoclonal antibodies against (E.M.A) and (C E.A.). The MANSOURA MEDICAL JOURNAL 
immunohistochemical method performed using indirect peroxidase (Naeim et al., 1982) (Peroxidase antiperoxidase PAP technique).

\section{RESULTS}

Immuno-Histochemical results table (I) shows the following :

\section{I) Antikeratin :}

- The normal respiratory epithelium and the mucous secreting glands failed to take the stain,

- The tumour : Eight out of nine cases show cytoplasm with homogenous and diffuse staining with moderate intensity.

\section{2) Anti C. E. A. :}

- The normal respiratory epithelium stains negative, while the mucoug secreting acini show faint positive staining.

- The tumour: Seven out of nine cases shows weak positive staining which is restricted to the suprabasal layers.
3) Anti E. M. A. :

- The normal respiratory epithelium shows weak positive staining in some cells however the glands failed to take the stain.

- The tumour : Five out of nine cases shows weak positive staining in the basal layer only. The inflammatory cells whithin the connective tissue stroma show no reactivity.

\section{DISCUSSION}

Inverted papilloma of the nose and para-nasal sinuses is a rather uncommon condition characterized by hyperplasia of the basal cells and invagination of the epithelium in the underlying stroma (Van Olphen et al., 1988). It forms a diagnostic problem especially when the bipsy is small specimen. Because it has a high recurrence rate, and also malignant transformation can occur in $2-20 \%$ of cases, it is important to make an effort to discover the premalignant cases (Kamal, 1981). In this study we use the polycolonal antikeratin antibody to test for the intermediate filament prekeratin characteristically expressed by the epithelial 
cells. The normal respiratory and glandular epithelium failed to take the stain with antikeratin antibody, while the neoplastic epithelium show moderate immunoreactivity with this antibody in 8 cases out of 9). This finding is consistent with the finding of Schlegel et al., (1980), and denote the expression of new cytokeratins in the neoplastic cells. This may be one of the predicting signs for further neoplastic transformation.

E. M A. a large glycoprotein, has been demonstrated normally on secretory and other epithelial surfaces of most nonsquamous tissues in humans (Ormerod et al., 1983). In the present study immunoreactivity to $E M A$. is found in 5 cases that give weak positive stain. A previous work done by Graham et al., (1980) and Muraro et al. (1985) showed the presence of the EMA marker in the eccrine, apocrine and sebaceous glands.

C E.A. which was originally thought to be a gastro-integt - inal specific marker has subsequently been demonstrated in a variety of non-gastro- intestinal tumours (Krisch et al.,1985). It is considered as a family of isoantigens which have multiple antigenic determinants, some of these determinants may be common to all the isoantigens and others may be antigenically distinct. In the present study C.E.A. givea weak positive immunoreactivity in 7 cases, while the normal respiratory mucosa is negative.

However the antikeratin antibody is more decessive in predicting further neoplastic transformation because neither E,M,A. nor C E.A. are present in all cases and also they are react weakely, but using the three epithelial markers together and recording the staining as positive or negative irrespective of the intensity of the staining we can distinguish the normal inflammatory from neoplastic area especially in tiny biopsies.

\section{SUMMARY}

The expression of keratin , carcino embryonic antigen (C.E.A) and epithelial membrane antigen (E.M.A) were studied in the epithelial linings of 9 cases of inverted papilloma of the MANSOURA MEDICAL JOURNAL 
nose and para-nasal sinuses, using suprabasal in 7 cases with C.E.A. and an indirect immunoperoxidase method basal in 5 cases with (E.M.A.) . on formalin fixed paraffin embeded Although these differences may not be sections. 8 cases were positive with of diagnostic significance, the conpolyclonal antibodies of keratin speci- stant expression of krratin may proficity. The pattern of expression of vide a useful marker of inverted papilC.E.A. and E.M.A. differed. It was loma. 

Tabie (1) : Shows the immuno - histochemical results of the nine cases, using the
three epithelial markers.

\begin{tabular}{|c|c|c|c|}
\hline \multirow{2}{*}{ Antibody } & Normal $R_{\epsilon}$ & espiratory Epithelium & \multirow{2}{*}{ Tumour } \\
\hline & \multicolumn{2}{|c|}{ Respiratory epith. Mucous Glands } & \\
\hline 1) Antikeratin. & Negative & Negative & $\begin{array}{l}8 \text { cases positive } \\
\text { with moderate } \\
\text { intensity. }\end{array}$ \\
\hline 2) Anti C. E. A. & Negative & Faint Positive & $\begin{array}{c}7 \text { cases weak } \\
\text { positive. }\end{array}$ \\
\hline 3: Anti E. M. A. & Weak positive. & Negative & $\begin{array}{c}5 \text { cases weak } \\
\text { positive. }\end{array}$ \\
\hline
\end{tabular}

Tacla (2): Are, sex distribution.

\begin{tabular}{|cccc|}
\hline Age / Years & \multicolumn{2}{c|}{ Sex } & Total \\
\cline { 2 - 4 } & Male & Female & \\
\hline $20-$ & - & 1 & 1 \\
$30-$ & 2 & - & 2 \\
$40-$ & 4 & 1 & 5 \\
$50-60$ & 1 & - & 1 \\
\hline
\end{tabular}


Table (3): Duration of symptoms of the patients studied.

\begin{tabular}{|lc|}
\hline \multicolumn{1}{|c|}{ Duration } & Number \\
\hline Less than One year. & 6 \\
2 years. & 2 \\
3 or more years. & 1 \\
\hline Total & 9 \\
\hline
\end{tabular}

Table (4) : Symptoms and signs of patients studied.

\begin{tabular}{|lc|}
\hline & Number \\
\hline - Unilateral nasal obstruction. & 9 \\
- Rhinorrhoea. & 5 \\
- Epistaxis. & 2 \\
- Nasal mass. & 3 \\
- Pain . & 7 \\
- Proptosis. & 7 \\
- Epiphon. & 2 \\
\hline
\end{tabular}

Table (5): Previous surgery performed to the patients.

\begin{tabular}{|c|c|}
\hline & Number \\
\hline Intra nasal polypectomy. & 2 \\
\hline Coldwell. & 2 \\
\hline Lateral. & - \\
\hline Total & 4 \\
\hline
\end{tabular}

Volume 21, 1991 


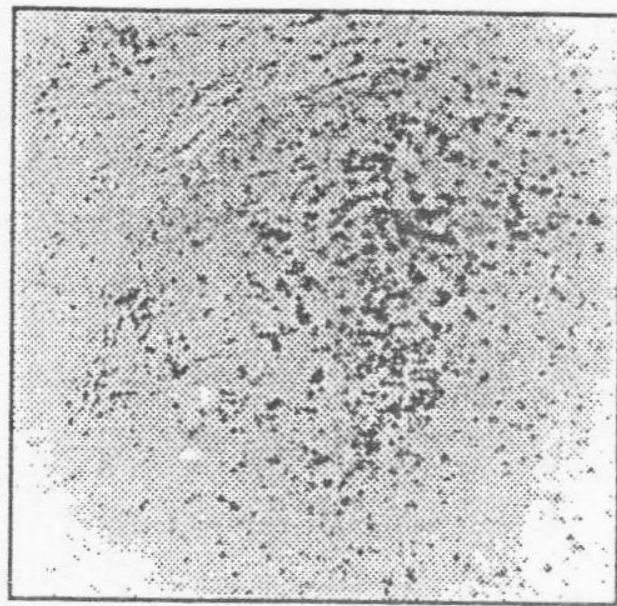

Fig. I : Immunoperoxidase staining of formalin fixed paraffin embeded inverted papilloma with antikeratin antibodies found diffuse in the cytoplasm of the cells. (X 100).

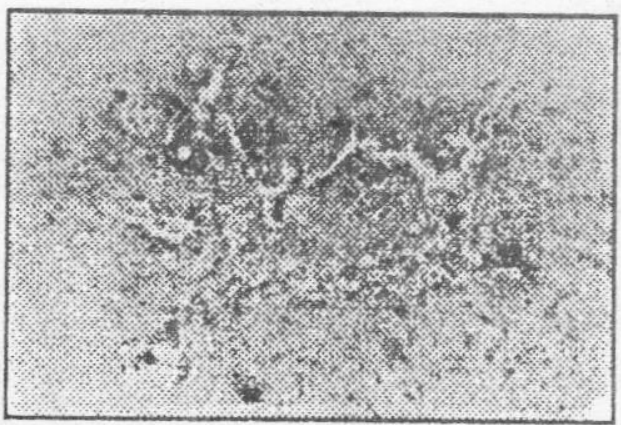

Fig. 2 : Immunoperoxidase staining of formalin fixed paraffin embeded inverted papilloma showing suprabasal antibodies of (C.E.A.) (X 100).

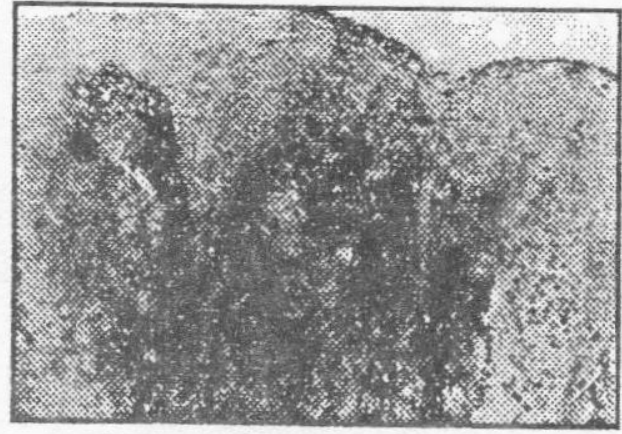

Fig. 3 : The same tumour shows basal staining of antibodies of (E.M.A.) (X1OO).

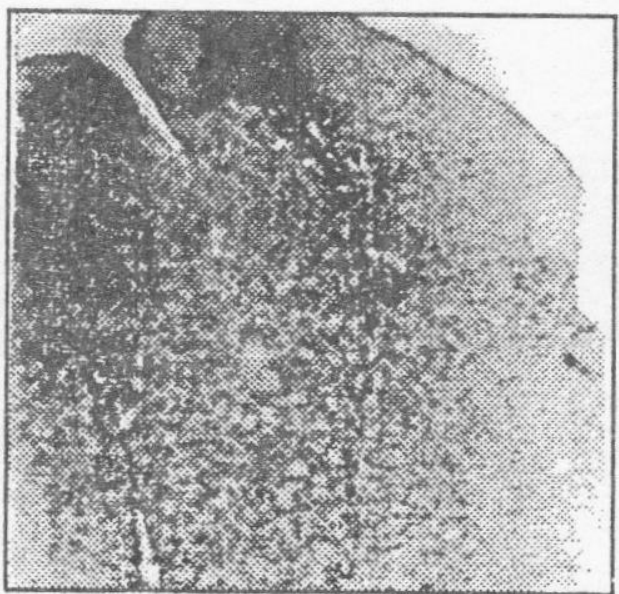

Fig. $4: \mathrm{Hx}$. and Eosin staining of inverted papilloma ( X 250).

MANSOURA MEDICAL JOURNAL. 


\section{REFERENCES}

Grahm, R. M.; Chapman, D. V.; Richardson, T. C.; McKee, P. H. and Heydeiman, E. (1980) : D.M. MacDonld, London Boston, Durban, pp. 55 - 59 Singapora, Sydney Toronto Wallington.

Kamal, S. A. (1981) : J. Laryngol Otol, $95: 106 \mathrm{~g}-70$.

Krisch, K. ; Krisch, I. and Horvat, G. (1985) : Histopathology, 9 : 1077 - 1089.

Muraro, D.; Wynderlich, A.; Thor, J.

: Kundy, P Noguchi, R.; Cunningham, R. and Sohlom, J (1985) : Cancer Research $45,5769-5780$.
Naiem, M. J.; Gerdes, J.; Abdulaziz, Z.; Sunderland, C. A. Allincrton, M J.; Stein, $\mathrm{H}$. and Mason, D. Y. (1982) : J. of Immunological methods. $50,145-160$.

Ormerod, M. G.; Steele, K.; Westwoud, J. H. and Mazzini,M N, (1983) ; Brit. J. Cancer. $48: 530-54:$.

Schlegel, R.; Banks-Schleref, S. : Mc Leod, J. A. and Pir kus, G.S. (1980) : Am. J. F anc! $101: 41-50$.

Snyder, R. N.; Perzin, K. H. (1972) : Cancer, $30: 688$ - 690 .

Van Olphen, A. F.; Lubsen, H. and Van Tveriaat, W. (1988) : J Laryngol Otol., 102 : 534 537. 


\section{دراسه مناعيه هستوكيميائية لدلالات الخلايا

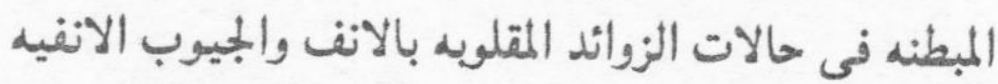

اجريت دراسات توضيح الكيراتين وانتيجينات السرطان الجنينى وانتيجينات الغشاء

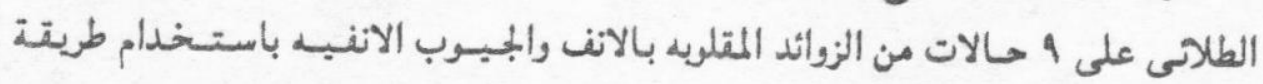

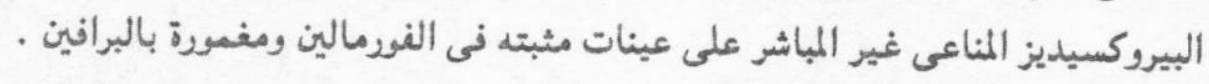

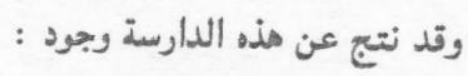

$$
\begin{aligned}
& \text { - A من حالات كانت ايبابية للكيراتين . }
\end{aligned}
$$

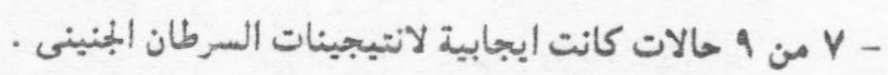

$$
\begin{aligned}
& \text { - مه من 9 حالات كانت ايبابية لانتيجينات الغشاء الطلانى . }
\end{aligned}
$$

وغم ان هذا الاختلاف قد لايكون ذات اهميد تشخبصية فان ظهور الكيراتين دائدا. يكن الاعتماد عليه كدليل نافع فى تشخيص الزوائد الانفيه المقلويه . 


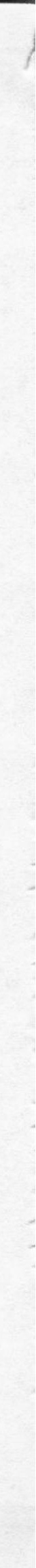

